\title{
Service Marketing and Quality Strategies
}

\author{
Yogesh Hole $^{1}$, Snehal Pawar ${ }^{2}$, Mahesh PBhaskar ${ }^{3}$ \\ ${ }^{1}$ Department of Public Administration, Cihan University-Erbil, Kurdistan Region, Iraq. \\ ${ }^{2}$ Cihan College School, Erbil, Kurdistan Region, Iraq \\ ${ }^{3}$ Samarth Group of Institutions Faculty of Management, At. Belhe, Junnar, Pune
}

\begin{tabular}{l} 
Article Info \\
\hline Article history: \\
Received Feb $12^{\text {th }}, 2018$ \\
Revised Apr $24^{\text {th }}, 2018$ \\
Accepted Apr $24^{\text {th }}, 2018$ \\
\hline
\end{tabular}

\section{Keyword:}

Service Marketing, Service Quality, Service Marketing Mix, Service Quality Strategy, Servqual, Customer Expectations,

\begin{abstract}
Marketing concept was formerly built on manufacturing based model with products and goods-centered, for mainly economic exchange. It was developed, commencing from the time of the Industrial Revolution. After its conception, the marketing ideas began and thereafter, broadened their perspectives to involve exchange, substitute and replace with more marketing activities than goods and products manufactured. The formation of several sub-disciplines of service marketing explained the logic of product value and brand creation, and it has transpired to address several broadened perceptions and realities. Service marketing creates more influential programs, based models and it is apparent in the prototypical features, which are identified as distinctive services apart from products, having Inseparability, Heterogeneity, Intangibility, and Perishability. Therefore, this review paper argues that all these characteristics basically; (1) do not differentiate services from products and goods; (2) The service marketing and quality strategies have derived the meaning from the product manufacturing perspective; and (3) They employ very inappropriate and normative strategies. Many services provide the basic foundation highly productive service-dominant views of many exchanges that take place in service marketing, from which, appropriate strategies can be generated.
\end{abstract}

\section{Corresponding Author:}

Yogesh Hole,

Associate Professor, Department of Public Administration,

Cihan University-Erbil, Kurdistan Region, Iraq.

\section{Introduction}

\subsection{Definitions of Service Marketing}

The main concept of Service Marketing is to enhance marketing strength and to develop better production value and customer relationship. This can relate to marketing a product or marketing services [1]. There has been an added prominence given to the service sector due to the very competitive nature of marketing in the prevailing global economy, where, the service marketing and quality marketing strategies have developed into a fundamental subject. Marketing services and quality marketing are very diverse from the marketing of products and goods, due to the unique attributes, characteristics, and nature of services, namely, Inseparability, Perishable, Heterogeneity, and Intangibility [2].

In the developed economic countries, employment plays a dominant role promoted through service jobs, with most of the jobs are newly developed come through service marketing and such growth happens from services [3]. The size of Service marketing organizations can vary from a local small business to large global corporations, while most government agency activities performed by nonprofit organizations include services [4]. The Association of American Marketing classifies services activities to provide benefits, and satisfaction to customers by the way of offering sale, provided with pre-sale as well as after-sales services. In fact, a 
product sold is an object, a device, and a physical item, while the service is a performance, deed, or an additional effort. Service marketing is with or without a sale of a product, but with special performances and effort to satisfy the customer [5].

\subsubsection{Service Marketing Features}

1.1.1.1. Intangibility Aspect: The product, marketed is physical, visible and distinct material, while Services are intangible. The service cannot be touched or viewed. For example, banks promote the sale of credit cards by emphasizing the conveniences and advantages [6].

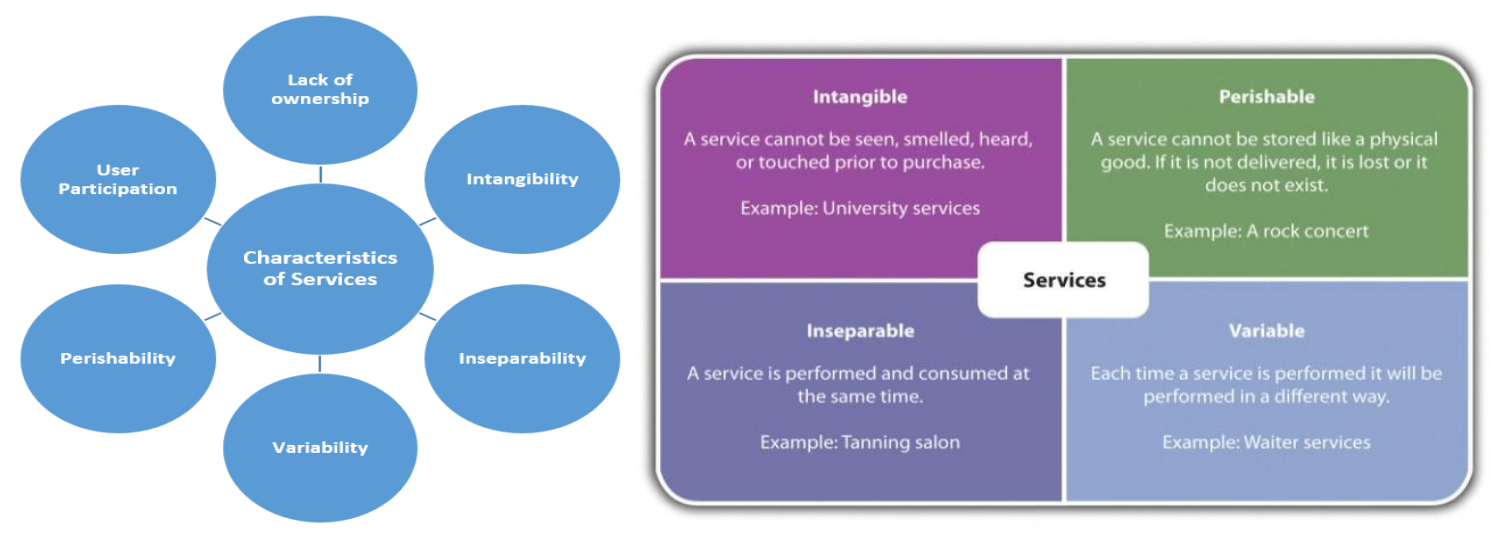

Figure 1: Service Marketing Features [7].

1.1.1.2. Inseparability: Personal services are also individual assistance because the Services are generated and consumed concurrently. The service is generated when the client receives it; for instance, during legal consultation, Dentist, Lawyers, musicians, generates and offers services altogether [8].

1.1.1.3. Variability or Heterogeneity: Services are for people, and the service quality cannot be standardized. This can be improved by proper training, setting standards and quality assertion [9].

1.1.1.4. Perishable: Services are highly perishable because services cannot be reused. The unused services are lost forever. For instance, the airplane seat cannot be relocated for the next flight. Similarly, services expire unless consumed.

1.1.1.5. Change in demand: The service demand has severe fluctuations, as they are seasonal. Tourism Demand is seasonal. Service demand for cricket field, public transport, and the golf course has demand fluctuations.

\subsubsection{Service Pricing}

Normally, services relate directly to customers. For instance, a service provider goes directly to the hotel, bank, and doctor [10]. Service Quality is not possible to standardize. Service pricing is determined based on competition, necessity, and demand. For instance, tourist spot room rent fluctuates due to season and demand. Several service providers offer off-season discounts.

\subsubsection{Direct channel}

\subsubsection{Problems related to Service Marketing}

1. The services are not possible to demonstrate;

2. Service marketing, production, and consumption take place altogether;

3. The services cannot be preserved or stored. It is not possible to generate anticipating demand;

4. Service protection cannot be made through patents;

5. Services are completely linked to service providers;

6. Services are inconsistent, cannot be standardized;

7. The Franchises of Service providers can face service quality problems; 
8. Regarding the service quality, customer perception is directly associated with motivation, morale, and skills of the forefront staff of the service organization [11].

\subsection{Customer Satisfaction \& Customer Loyalty}

Due to globalization, the services sector value and importance have grown and that relates to technological advancements and business competition. Therefore, e-commerce prominence, market access is no more localized. Hence, the logistics and distribution have become a critical competitive force and hence, have observed innovative applications. For example, Project Shakti of Hindustan Unilever involved rural women of underprivileged families to distribute their products. $P \& G$ products are seen in mom-and-pop stores, and they started adopting innovative ways to distribute products in promising markets [12]. Also, due to increasing market fragmentation, companies started locating various smaller customer segments, who need personalized service marketing [13].

The Service related companies encounter service quality differentiation problems from their competitors. For example, the brands of the USA retail, industrial stores compete extensively with national brands for marketplace dominance. The survey states that around $82 \%$ of USA shoppers prefer private brands; $86 \%$ trust private and national brands equally; the sale of the private brand is more by $4 \%$ than national brands [14]. This is because, people take a closer look at the experience-focused services offered and the relationship developed, besides quality product and price and that gains the competitive advantage. This reflects on a few research questions:

RQ1: In this competitive fragmented market, a service quality strategy makes a lot of difference. Therefore, service companies must adapt to offer genuine and valid value to serve customers with personalized offerings? RQ2: Marketing communication strategy and plans can be instituted by integrating various communication technologies and mediums, to influence customers?

The electronic channels have generated tremendous impact. The customers can freely interact using a multitude of channels. The social media combined with mobile technology has offered a valuable access line to develop new communication patterns, resulting in companies to equip and test the Omni-channel models, which mainly focus on the channel interplay with brands [15]. Hence, the Omni-channel concept extends further than channel management, involves a flawless transition between different channels, to provide superlative user experience [16].

\subsection{Service Quality, Its Importance in Marketing, and Competitive Strategies}

The researchers, authors, and academicians have investigated the conceptualization of quality and services rendered and the connection between consumer satisfaction, service quality, and buying intentions. The literature review indicates that the prevailing service quality operations and optimization of confounded attitude and satisfaction can be measured [17]. Therefore, they attempted to test (1) The alternative methodology to assess the operational service quality perceived by customers; and (2) the implication, significance, and consequence of affiliations between the quality of service, related consumer satisfaction, and the purchasing intentions. The overall results suggested that (1) There is a measure, based on performance and service quality, which can be improved, which also indicates the measuring of service quality structure and construct, (2) The consumer satisfaction entirely depends on the service quality; (3) The consumer satisfaction is very significant, and its effect completely decides the purchase intentions; and (4) The service quality creates lesser effect on purchasing intention than what consumer satisfaction does [18].

\subsection{Mapping on factors affecting customer satisfaction}

The growing value, importance, and concept of the service marketing sector in practically every world economy has generated a considerable amount of attention and awareness in their service operations [19]. In reality, several service marketing sectors have implemented and sought advanced applications and tried to apply for several enhancement programs so as to improve and promote their operations 
standards and work performance with an intention to hold and promote competitive success. All the researchers have appreciated the concern for the intensive service operations linkage with customers. Therefore, the customers as the main participants started acting in the service marketing and operating system specifically derived by the specific objectives and goals to provide an added value to the ir performance [20]. This makes a service marketing facility a distinctive feature of production, creation, and consumption. Therefore, there is a proposal that the service operation ideas can be improved by mapping without prejudice, allowing the customers to view the service quality and experience in their service journey. Secondly, a proper portraying and depicting the service experience scheme by customers can be applied with various techniques, and lastly, certain service implications of operational improvement can be produced [21].

\subsection{The dimensions of service quality}

Services are considered as procedures. Therefore, the service organizations do not supply products that are considered to be manufactured and produced as physical bundles of resources with specific features. Instead, marketing of product consumed by customers can also integrate with service facilities, but the service marketing process has different functions, to provide a solution to perceived obstructions [22]. Hence, the service facilities are characterized as a consuming process, which is different than outcome consumption, where the specific process outcome is utilized and consumed [23]. The service firms offer processes to solve problems of customers, where the physical nature of the products is not involved, but based on the nature of services, fulfillment of service promises with external marketing, the behavior, and attitudes of service marketers. Moreover, in the service marketing system, the operating systems must be customer oriented. The service marketing provides proper solutions to customer problems, which is the objective of the service marketing, and the dimensions of service quality and the concept can substitute the product construct with the planned customer oriented procedure [24].

\subsection{Customer Satisfaction as a Mediating Effect}

The Strategic Service Quality maintained in the service marketing sector has a very valuable impact and increasing concern for both practitioners and academicians [25]. The previously published articles have identified, the material is observed and viewed with their attention specifically focused on the significance of servicing people and their internal marketing ability in this ever-varying service industry environment, with added definitions, capacity of service quality, and their breadth and dimension of the service quality, customer care programs currently developed, assessed and implemented [26].

The results show that the dimensions of the service quality, the perceived cost, the fairness of service and the measure of convenience can generate a positive impact on customer contentment and satisfaction and that provide assured customer loyalty [27]. Apart from that, customer satisfaction accomplishes as a major mediating adjustment between its service marketing professionals, antecedents and customer loyalty [28]. This review paper, therefore, underlines the significance of customer satisfaction to achieve customer loyalty. Also, the impact generated by various model dimensions like Servqual related to customer loyalty is rarely observed in the literature [29]

Research based on cross-sectional aspects with 455 customers of retail banking was conducted and surveyed through questionnaires. It was a Population study of various banks in Rajasthan, India, and valued as retail urban banking customers, who happened to be frequently visiting bank premises for business operations and transactions. Most of them had at least two bank accounts and they availed of minimum one IT- Information Technology generated services. All their responses were analyzed by applying the factor and regression analysis method [30].

This review supports and highlights the need for managers to obtain more resources to develop a superior CRM system. Hence, the managers have to think further than the technological viewpoint, with a focal 
point on four basic dimensions, particularly the customer information, facts, and knowledge, so as to improve the customer loyalty and to get a better competitive edge [31].

A comprehensive and integrated model can be developed to help assess, and explain the CRM - Customer Relationship Management impact, its dimensions of customer knowledge, complaint resolution, customer empowerment, and orientation, along with customer loyalty, competitive advantage for the bank to measure. The review also explores the customer loyalty mediating role in the competitive advantage and a CRM relationship in the retail banking sector [32].

\subsection{Managerial Implications}

The emerging service marketing dominated logic clarifies that only customers can generate values, while the companies can make only value propositions. The managerial role and implication of marketing are framed beyond the conventional boundaries. Generating customer value by managerial functions is a multifaceted procedure two conceptually and distinct subprocesses. The supplier's process provides resources for the use of customers, while the customer's procedures turn services into values. Therefore, the main five service logics shown below provide a clear understanding of the value creation process, together with implications for marketing. These provide a terminology to help researchers understand several roles customers and suppliers can play in value creation, find opportunities for collectively creating values [33].

The reliable and the most valid method to measure the service quality is based on a wide range of conceptual framework, integrating the concepts and theory to assess the quality of customer service, information systems, and product portfolio level of management, regarding the online process service quality [34]. An ethnographic and comfortable content analysis and reviews of 858 banking customer online service were employed to recognize salient features of service online quality dimensions. The frequently observed online quality of service was attributed together with a personal interview and literature review results, and the survey was developed through the questionnaire process. Subsequently, the pre-test and a Web-generated survey were employed to test and verify the online quality of services rendered [35]. The literature review indicated that the analysis of customer portfolio provides strategic quality service level input to their customers towards successful planning and developing process. Such conceptual discussion, Managerial Service Quality Implications, and Relationship Management have resulted in the strategies Service Marketing quality improvement in the corporate social measure of capital. Another method was developed with reference to the prevailing market environment together with the value concepts to understand the relationship between the organizations, customers and suppliers and that completely reflected on the contemporary ability and implications of managerial perception [36].

This was confirmed by factor analysis and that produced six major factors to assess the quality of service online with dimensions, like competence, product portfolio, security, responsiveness, reliability, and ease of use. Therefore, there is an intense responsibility for the managerial activities and abilities to satisfy customers and also have major theoretical implications of service quality. Managerial performance and implications can help plan and generate strategies to improve customer relationship and optimize returns over time [37].

\section{Service Marketing Methods}

Customer-related performance and service marketing quantifications are gauged by their association with the segmentation strategies and generic positioning while considering strategic positioning with low-cost service differentiation, and they are indirect, instead of directly related to the business growth and performance. Both of these strategies of the firm concurrently pursue low cost based services, differentiated analysis, and strategies leading to an enhanced performance in most of the service companies [38]. Therefore, the objective of this investigative analysis to to locate the link between the 
measures of customer based service performance, those of marketing measures of the company success, and the related performance for the business growth, which means strategic measures of company success, related to strategic service marketing positioning decisions related to customer related and that a help find the main role to measure the overall business progress and achievements [39]. The companies, which fail to measure the service marketing performance at the level of customers may fail to understand the successful outcome of marketing programs and related to service decisions. Further, the operational efficiency along with differentiation are the key factors to the growth of business services [40].

\subsection{Servqual model}

Research conducted to measure the quality of airline services and its influence on customer loyalty and satisfaction had created a major issue for researchers, because it has a potential to enhance airline competitiveness and profitability [41]. Even in the absence of holistic quality measures, the service quality can be assessed from the customer point of view [42], because, as per [43], the service quality value becomes inherently subjective. [44] recommended the SERVQUAL method to measure the service quality as realized by customers. The SERVQUAL model has five dimensions, labeled as Assurance, Reliability, Empathy, Tangible, and responsiveness.

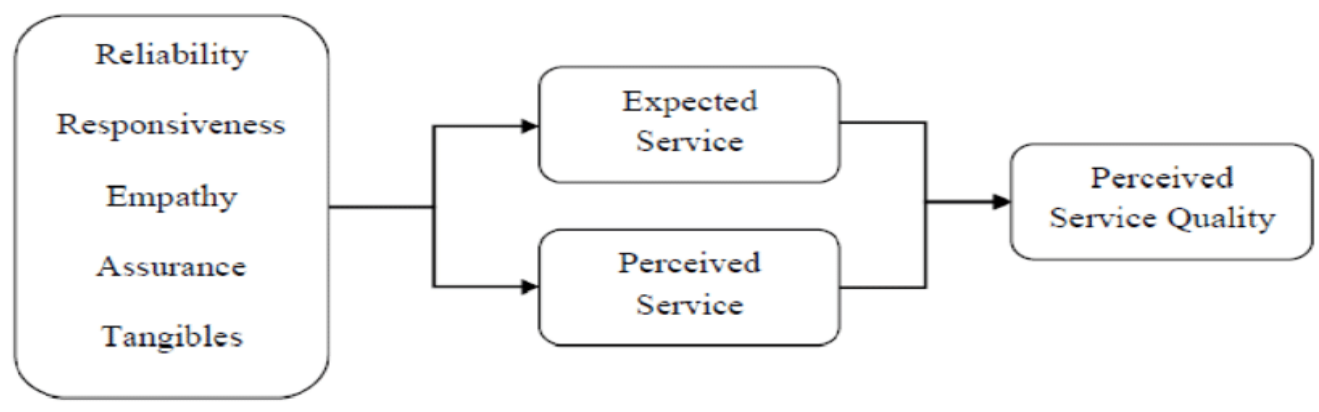

Figure 2: SERVQUAL model [44]

According to [44], consumers always assess the quality of service and compare their expectations with observations, and perceptions depending on these five dimensions of the above figure. Reliability indicates the business organization capability to act and perform as promised to provide services adequately and dependable [45]. The Responsiveness indicates the readiness or willingness to provide immediate service. Assurance concerns with the employee knowledge level and the courtesy level that inspire customer confidence and their expectations. Tangible indicates the physical appearance and the service presentation, equipment get up and service facility offered to customers. The empathy has to do with employee consideration for individual attention, and knowledge to understand the customer needs [46].

In the case of Service quality SERVQUAL model, it will hinge the variance in quality of service to specify differences in quality of service expected and perception. The broader the variance, the less quality perception appears in the minds of consumers, and vice-versa [47]. The SERVQUAL method is always applied to assess the degree of Gap, which elaborates the variations between customer perceptions, expectations and service quality.

Out of five major service quality Gaps, only Gap 5 can be measured specifically from the customer point of view, which means, the other Gaps analyses require data assistance from the service providers. Even though its application, and effectiveness vary, several researchers have recorded some SERVQUAL model limitations and offered alternative models to evaluate and measure the quality of service [50]. These academics stated regarding the service quality views and various unique factors, which are industry-specific; therefore, no specific measurement model can be applied universally in all the industries [51]. Particularly, they mentioned that SERVQUAL describes the customer satisfaction level related to product and service, but not the quality of service rendered [52]. 


\subsection{Service quality model}

Therefore, the scholars, in 1992, developed the model of SERVPERF to assess overall feelings of customers towards the delivery of service [53]. Another development of service quality model to solve the SERVQUAL shortcomings are the service quality synthesized model [54]. The service quality attributes model was developed by [55], which was the core, pivotal, and peripheral model, among others. They formed another refined five SERVQUAL dimensional model converted to a seven-stage model indicating [55].; Assurance, Reliability, Customization, Responsiveness, Employee, Flight pattern, and facilities as shown in [49]. Until then, there were no specific methods to measure the service quality and researchers accepted that the SERVQUAL seven dimensions provide multifaceted results important for studying and measuring service quality [56].

\section{Importance of Marketing Research for Service Industry}

The market research importance is that the business organization gains a suitable solution to develop business processes, improve company performance, increase profits, investigate competitors' motive and activities and obtain additional satisfied customers [59].

Market Research is a constant process of investigating, collecting, and interpreting the gathered information concerning the specific service marketing, the company operates. It is also concerning market potential, the past and prevailing competitors, potential customer details, which consume them and prefer to obtain services. Performing market research is to make an analysis of complete market information about the services needed, likely customers, competitors so ass to investigate probable ways to successfully perform service marketing operations, attract and invite the target customers and further gain competitive benefits [60].

Designing, planning and making a suitable framework for market research is the prime duty of marketing teams. The company must organize the market research consistently to obtain the market insight, investigate customer spending habits, identify potential and existing competitors, construct product promotion solution, advertise, promote, and enhance company image, recognition, value and improve business reputation. The market research provides the company vital business planning methods and solutions to promote the company's performance, build up sales and intensify revenue [61].

\subsection{Marketing Research Process}

Market research provides better opportunities to increase sales, get the feel of the market to gain valuable information, identify the successful service methods, and they offer the best price for the services rendered. The Market research helps improve Customer Management, provides adequate tools of a marketing campaign, like messaging, meetings, questionnaires, discussions, so as to reach a large audience of clientele, reduce the timeframe to perform a service task, investigate prevailing and future customer expectations and needs, and provide better customer satisfaction. The main business growth can be achieved with a proper business plan, and research, by which, the customer management improves and the company gets an opportunity for business development [62].

Customers normally prefer to deal with companies having better previous experience with service-related activities, as per the research Georgia State University team of Business research at the J. Mack Robinson Institute. The researchers observed the basic experience and important knowledge of service companies and their focus on efforts and resources to improve customer experience and satisfaction [63]. The researchers also found that the satisfied customers evaluate the performance of company service, and that affects their commitment to creating the maximum positive impact on the loyalty of customers, while the enforced commitment to generate maximum negative impact [64].

\subsection{Defining the problem and determining market research Objectives}

Service marketing in terms of two main criteria defines a good research method with data integrity, high accuracy without conflicting demands of operation of researchers. The tradeoff should be to employ a suitable 
method to identify and investigate the research problems. As a result, such inevitable trade-offs, with a broader method will be a suitable solution for marketing investigations. The research needs to explore some other valuable research alternative method for marketers to provide better performance. The nature of research should prove to be a scientific case with appropriateness to gain the researcher's objectives and solve the problems investigated [65].

Service marketing sustainability is the main criterion to evaluate the research outcome. Thereafter, there is a need to illustrate the inherent difficulties to apply such criteria and eventually draw the implication for further research. There are several propositions related to sustainability. The researchers urge to (1) Comprehend the value of the sustainability of service marketing systems; (2) Formulate adequate means to measure sustainability; (3) Empirically assess the sustainability level with well-defined systems; (4) Define the external problems existing in the systems; and (5) Generate systems to measure those external problems [66].

The review motivates, demonstrates, and presents the methodology to conduct research on DS- Design Science in IS- Information Systems. DS is important for discipline oriented creation for successful work of servicing art. Many researchers have initiated the link to apply DS research with IS, but hardly any DS research has been processed within this subject. In the absence of proper methodology with accepted DS framework, the adoption process is slow. The DSRM - Design science research methodology emphasizes the need to incorporate procedures, practices, and principles to conduct such research and meet three specific objectives. (1) It should be consistent and in line with prior literature available. (2) It needs to provide a simple processing model for performing the DS research; and (3) It should provide a thoughtful model to present and evaluate DS research to link with IS. The procedure of DS contains six stages: evaluation, design, and development, defining objectives for a solution, demonstration, problem identification, motivation, and communication. The evaluate of the methodology can be demonstrated by the DSRM case studies, including database design supporting assessment methods, the reuse of software measure, a video, Internet and telephone applications, and an IS- Information System planning method. The methodology so effectively designed should satisfy three objectives having the potential that help aid the DS research acceptance in the IS regulations [67].

\subsection{Scope for future research}

In the past several decades the concept and applications of service marketing have appeared and materialized as the most authenticated and established a subject region of analysis to probe in the marketing sectors. In several ways, its acceptance and growth as a valuable marketing function have generated higher scope in the academic and research arena that is indeed noteworthy. However, the basic question arises regarding the direction in which the services marketing concept, process, and applications should move and its field of study should drive the future course. Therefore, this review content analyzes the imminent factors that provide insights and builds on an extended history of the service marketing process and the research intends to generate the impact on the scope and methods of marketing considering the companies interact with customers and suppliers [71].

This scope concludes with a short consideration of costs in relation to its benefits, system outline, design, and implementation matters, along with the other potential AI- Artificial Intelligence technology to contribute to services marketing implications and management. The advanced and progressive applications of such proficient systems will considerably change the services marketing, competitive landscape in the future [72].

\subsection{Service Marketing as a quality strategy}

Competition in the prevailing service industry business is now intensifying and this aspect has now become additional important for service marketing companies to improve the quality service as a major factor to gain marketing competitiveness. Hence, the quality of service should be observed as a prominent approach to improve service competition. The strategies implemented for maintaining the competitive 
service can vary, but the service quality must be excellent, approved by customers, and should meet all variations in serving customer needs, purchasing manners and consumption arrangements [73]. The service quality perception presents a basic model, recognized in service marketing oriented sources as PSQM- Perceived Service Quality Model [74].

The Marketing Managers and Service Marketers always look for proper methods and instruments to measure service quality, so as to identify the service quality features and determinants. The SERVQUAL processing model depends entirely on attributed approach to assess service quality, and illustrate five main service quality determinants as reliability, tangibles, assurance, responsiveness, and empathy [75].

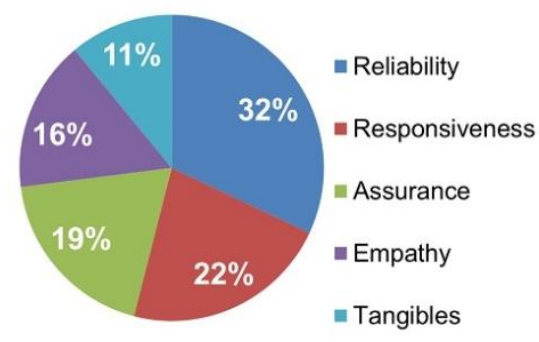

Figure 3: Five main service quality determinants [76].

Service marketing companies must focus on implementing the service quality strategy, develop and improve so as to satisfy their customers properly, by conducting internal, and competitor analyses while evaluating the market trends, to gain competitiveness [77].

\section{Service quality strategy Challenges, future trends, and Scope}

Very fewer articles are linked to ES application and classification schemes. On the basis of various reviews, the database tries to provide the ES categorization in the service sector industry and further tries to seek an elaborate future needs related to vital information and technology in service undertakings and operations. This improves the managerial understanding of ES concepts and technology to provide a clear perspective as to how ES should be applied in service operations [78].

Based on the ES, Intelligent methods try to solve practical and complicated problems in different sectors. The ES is developed as well as deployed all over the world in countless applications, particularly due to their symbolic interpretation and their explaining capabilities. It reveals that, although the ES concept is already matured to a stage to offer real practical solutions and benefits in several applications [79].

Service marketing triangle underlines the link between several service providers with customers who need and consume such services. The proper communication, relationships, and mutual understanding are the vital aspects of the services sectors. Therefore, the service triangle elaborates the entire relationship procedures, principles, and expressions that exist between Service marketing companies, their employees and their customers [81].

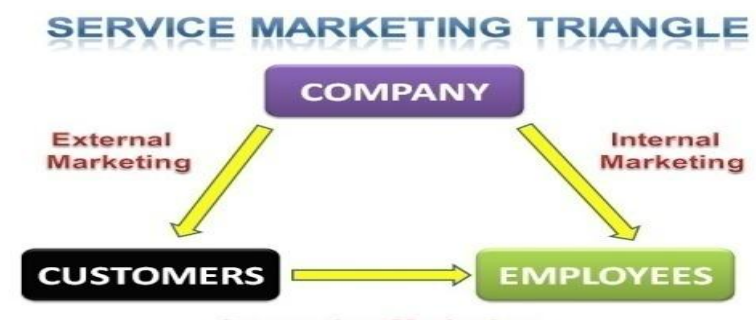

Interactive Marketing

Figure 4: Service marketing triangle 
Three types of service marketing progress within the service marketing triangle; (1) Internal marketing, which relates the Marketing aspects of the Service marketing company to their employees; (2) External marketing procedures emphasize the role of Service Marketing directly to their customers; (3) Interactive marketing operates the Marketing aspects between their customers and their employees [80].

\section{Conclusion \& Discussion}

This review paper has explored to characterize the service as any performance or act that one party is capable of offering to another with essential and intangible features without the exchange of physical products [82]. Moreover, service is an intangible product, is related to marketing activities, instead of selling objects, and hence, encounter service marketing problems, which can possibly be solved by traditional product-based marketing solutions [83].

Background: The service marketing encounters a certain moment when the client directly and consistently interacts with the service marketing companies. It remains as social oriented performance activities and the indepth analysis can substantiate the fact how the behavior of client contributes to the quality of service, which can be measured to assess how well the service level performs to customer beliefs, expectations, and needs on a regular basis and delivers to complement customer expectations [82]. This review has tried to explore several service marketing methods together with a quality framework of the service marketing mix, and SERVQUAL the services marketing triangle and service-dominant logic [83].

It has become apparent that service marketing is the most imperative and commanding sector industry to conduct and gain proficiency because they have cultivated positive links with customer satisfaction [84].

Furthermore, due to the high significance of service marketing and their quality issues, several frameworks have been generated as emphasized before. The 7Ps, and services marketing triangle collectively combines two major factors in their comprehensive framework to outline service marketing- external, internal, interactive; and mediums. The SMT - services marketing triangle has turned out to be the latest approach to enforce service quality along with marketing, while there is a consistent, especially advancement in technology and that has delivered the best quality service for the continuous success in the service market [85].

\section{References}

[1] Suhail Ahmad Bhat, Mushtaq Ahmad Darzi, "Customer relationship management: An approach to competitive advantage in the banking sector by exploring the mediational role of loyalty", International Journal of Bank Marketing, Vol. 34 Issue: 3, pp.388-410, 2016. https://doi.org/10.1108/IJBM-11-2014-0160

[2] Barbara R. Lewis, "Quality in the Service Sector: A Review", International Journal of Bank Marketing, Vol. 7 Issue: 5, pp.4-12, 1989. https://doi.org/10.1108/02652328910134590

[3] Vargo, S. L., \& Lusch, R. F. 'Evolving to a New Dominant Logic for Marketing', Journal of Marketing, Vol. 68 (1), Page. 1-17. 2004. http://courses.ischool.berkeley.edu/i210/f07/readings/VargoLusch.pdf

[4] Abela, A. V., and Murphy, P. E. (2008). Marketing with integrity: ethics and the service-dominant logic for marketing. Journal of the Academy of Marketing Science, 36(1), 39-53. https://link.springer.com/article/10.1007\%2Fs11747-007-0062-0

[5] Bloom, P. N., \& Perry, V. G. Retailer power and supplier welfare: The case of Wal-Mart. Journal of Retailing, 77(3), 379. 2001. https://www.sciencedirect.com/science/article/abs/pii/S0022435901000483

[6] Christian Grönroos, "Marketing services: the case of a missing product", Journal of Business \& Industrial Marketing, Vol. 13 Issue: 4/5, pp.322-338, 1998. https://doi.org/10.1108/08858629810226645

[7] Dana-Nicoleta Lascu and Kenneth E. Clow, Essentials of Marketing, Mason, OH: Atomic Dog Publishing, 264-68. 2007, https://saylordotorg.github.io/text_small-business-management-in-the-21st-century/s11-05marketing-strategy-and-product.html 
[8] Terrence Levesque, Gordon H.G. McDougall, "Determinants of customer satisfaction in retail banking", International Journal of Bank Marketing, Vol. 14 Issue: 7, pp.12-20, 1996. https://doi.org/10.1108/02652329610151340

[9] Kanokkarn, Snae, Namahoot, Tipparat Laohavichien, "Assessing the intentions to use internet banking: The role of perceived risk and trust as mediating factors", International Journal of Bank Marketing, Vol. 36 Issue: 2, pp. 256-276, 2018. https://doi.org/10.1108/IJBM-11-2016-0159

[10] Anthony Larsson, Yamit Viitaoja, "Building customer loyalty in digital banking: A study of bank staff's perspectives on the challenges of digital CRM and loyalty", International Journal of Bank Marketing, Vol. 35 Issue: 6, pp.858-877, 2017. https://doi.org/10.1108/JJBM-08-2016-0112

[11] Gabriel Sperandio Milan, Luiz Antonio Slongo, Luciene Eberle, Deonir De Toni, Suélen Bebber, "Determinants of customer loyalty: a study with customers of a Brazilian bank", Benchmarking: An International Journal, Vol. 25 Issue: 9, pp. 3935-3950, 2018. https://doi.org/10.1108/BIJ-08-2017-0231

[12] Reinartz, W.J, Dellaert, B.G.C, Kumar, V, Krafft, M, \& Varadarajan, R. Retailing innovations in a globalizing retail market environment. Journal of Retailing, 87, Supplement 1, 2011. Doi:10.1016/j.jretai.2011.04.009

[13] Mohammed Rafiq, Pervaiz K. Ahmed, "Advances in the internal marketing concept: definition, synthesis and extension", Journal of Services Marketing, Vol. 14 Issue: 6, pp. 449-462, 2000. https://doi.org/10.1108/08876040010347589

[14] Siegner Cathy, "Report: Private Brands Entering a "Renaissance Period," FoodDive, 2018, https://www.fooddive.com/news/grocery-report-private-brands-entering-a-renaissance-period/516076/.

[15] Verhoef, P. C., Kannan, PK., \& Inman, J. From Multi-Channel Retailing to Omni-Channel Retailing: Introduction to the Special Issue on Multi-Channel Retailing. Journal of Retailing, 91 (2), 174-181. 2015. https://www.researchgate.net/publication/274404553_From_Multi-Channel_Retailing_to_Omni-

Channel_Retailing

[16] Brynjolfsson, Erik, Hu, Yu Jeffrey, \& Rahman, Mohammad S. "Competing in the Age of Omni-channel Retailing,” MIT Sloan Management Review, 54 (4), 23-29. 2013. https://sloanreview.mit.edu/article/competing-in-the-age-of-omnichannel-retailing/

[17] Gordon E. Greenley, "An Understanding of Marketing Strategy", European Journal of Marketing, Vol. 18 Issue: 6/7, pp. 90-103, 1984. https://doi.org/10.1108/EUM0000000004794

[18] Chetty, Raj, Hendren, Nathaniel, Kline, Patrick, \& Saez, Emmanuel, "Where Is the Land of Opportunity? The Geography of Intergenerational Mobility in the United States," Quarterly Journal of Economics, 129 (4), 1553-623. 2014. https://www.nber.org/papers/w19843.pdf

[19] Boyt, T. E., Lusch, R. F., \& Naylor, G. The role of professionalism in determining job satisfaction in professional services: A study of marketing researchers. Journal of Service Research, 3(4), 321. 2001. https://arizona.pure.elsevier.com/en/publications/the-role-of-professionalism-in-determining-job-satisfactionin-pr

[20] Chaudhuri, A., \& Holbrook, M. B. The chain of effects from brand trust and brand affects to brand performance: The role of brand loyalty. Journal of Marketing, 65, 81-93. 2001. https://www.scirp.org/reference/ReferencesPapers.aspx?ReferenceID=1808381

[21] Mitchell M. Tseng, Ma Qinhai, Chuan Jun Su, "Mapping customers' service experience for operations improvement", Business Process Management Journal, Vol. 5 Issue: 1, pp. 50-64, 1999. https://doi.org/10.1108/14637159910249126

[22] Ralph G. Kauffman, "Influences on organizational buying choice processes: future research directions", Journal of Business \& Industrial Marketing, Vol. 11 Issue: 3/4, pp.94-107, 1996. https://doi.org/10.1108/08858629610125496

[23] Jaakko Aspara, Henrikki Tikkanen, Erik Pöntiskoski, Paavo Järvensivu, "Exploration and exploitation 
across three resource classes: Market/customer intelligence, brands/bonds and technologies/processes", European Journal of Marketing, Vol. 45 Issue: 4, pp. 596-630, 2011. https://doi.org/10.1108/03090561111111352

[24] Christian Gronroos, "Marketing services: the case of a missing product", Journal of Business \& Industrial Marketing, Vol. 13 Issue: 4/5, pp.322-338, 1998. https://doi.org/10.1108/08858629810226645

[25] Min Hua Lu, Chu Hua Kuei, "Strategic marketing planning: a quality function deployment approach", International Journal of Quality \& Reliability Management, Vol. 12 Issue: 6, pp. 85-96, 1995. https://doi.org/10.1108/02656719510089948

[26] Nelson Oly Ndubisi, "Relationship marketing and customer loyalty", Marketing Intelligence \& Planning, Vol. 25 Issue: 1, pp.98-106, 2007. https://doi.org/10.1108/02634500710722425

[27] Patrick Hartmann, Vanessa Apaolaza Ibáñez, F. Javier Forcada Sainz, "Green branding effects on attitude: functional versus emotional positioning strategies", Marketing Intelligence \& Planning, Vol. 23 Issue: 1, pp.9-29, 2005. https://doi.org/10.1108/02634500510577447

[28] Michael John Valos, Fatemeh Haji Habibi, Riza Casidy, Carl Barrie Driesener, Vanya Louise Maplestone, "Exploring the integration of social media within integrated marketing communication frameworks: Perspectives of services marketers", Marketing Intelligence \& Planning, Vol. 34 Issue: 1, pp.1940, 2016. https://doi.org/10.1108/MIP-09-2014-0169

[29] Crane, A., \& Desmond, J. Societal marketing and morality. European Journal of Marketing, 36(5/6), 548-560. 2002. https://www.emeraldinsight.com/doi/abs/10.1108/03090560210423014

30] Eggert, A., \& Helm, S. Exploring the impact of relationship transparency of business relationships: A cross-sectional study among purchasing managers in Germany. Industrial Marketing Management, 32 (2), 101. 2003. https://www.sciencedirect.com/science/article/abs/pii/S0019850102002249

[31] Day, G., \& Montgomery, D. Charting new directions for marketing. Journal of Marketing, Vol 63. Page. 3-13. 1999. https://journals.sagepub.com/doi/abs/10.1177/00222429990634s102

[32] V. Kumar. Transformative Marketing: The Next 20 Years, Vol 82, Issue 4, 2018, https://journals.sagepub.com/doi/10.1509/jm.82.41 VIMP

[33] Pakdil, F., Aydin, O. Expectations and perceptions in airline services: An analysis using weighted SERVQUAL scores. Air Transport Research Management, 13, pp. 229-237. 2007. https://www.sciencedirect.com/science/article/abs/pii/S0969699707000385

[34] Russell Abratt, Nicola Kleyn, s"Corporate identity, corporate branding and corporate reputations: Reconciliation and integration", European Journal of Marketing, Vol. 46 Issue: 7/8, pp. 1048-1063, 2012. https://doi.org/10.1108/03090561211230197

[35] Zhilin Yang, Minjoon Jun, Robin T. Peterson, "Measuring customer perceived online service quality: Scale development and managerial implications", International Journal of Operations \& Production Management, Vol. 24 Issue: 11, pp.1149-1174, 2004. https://doi.org/10.1108/01443570410563278

[36] Rajagopal, Romulo Sanchez, "Analysis of customer portfolio and relationship management models: bridging managerial dimensions", Journal of Business \& Industrial Marketing, Vol. 20 Issue: 6, pp. 307-316, 2005. https://doi.org/10.1108/08858620510618147

[37] Arora, N., Dreze, X., Ghose, A., Hess, J. D., Iyengar, R., Jing, B., et al. Putting one-to-one marketing to work: Personalization, customization, and choice. Marketing Letters, Vol. 19, issue. 19. (3-4), Page. 305-321. 2008. https://link.springer.com/article/10.1007/s11002-008-9056-z

[38] Verhoef, Peter C. , Kannan, P.K. , and Inman, J. Jeffrey "From Multi-Channel Retailing to OmniChannel Retailing: Introduction to the Special Issue on Multi-Channel Retailing,” Journal of Retailing, 91 (2), 174-81. 2015. https://www.sciencedirect.com/science/article/abs/pii/S0022435915000214

[39] Yolanda Polo and F. Javier Sese. Does the Nature of the Interaction Matter? Understanding Customer 
Channel Choice for Purchases and Communications. Journal of Service Research 19:3, 276-290. 2016. https://journals.sagepub.com/doi/10.1177/1094670516645189

[40] Debra Zahay, Abbie Griffin, "Marketing strategy selection, marketing metrics, and firm performance", Journal of Business \& Industrial Marketing, Vol. 25 Issue: 2, pp. 84-93, 2010. https://doi.org/10.1108/08858621011017714

[41] Gour C. Saha, Theingi, "Service quality, satisfaction, and behavioral intentions: A study of low cost airline carriers in Thailand", Managing Service Quality: An International Journal, Vol. 19 Issue: 3, pp.350372, 2009. https://doi.org/10.1108/09604520910955348

[42] Sein, M., Chey, C. K. Demographic factors in the evaluation of service quality in higher education:

A Structural Equation Model (SEM) approach. International Journal of Marketing Studies; 6 (1), pp. 90-102. 2013. https://content.sciendo.com/view/journals/ijme/52/1/article-p94.xml

[43] Rhoades D., Waguespack B. Service and safety, quality in US airlines: Pre- and post-September 11th.

Managing Service $\quad$ Quality, $14 \quad$ (4), $\quad$ pp. $\quad 307-316 . \quad 2004$. http://www.academia.edu/7692003/Airline_service_quality_Exploratory_analysis_of_consumer_perceptions_ and_operational_performance_in_the_USA_and_EU

[44] Parasuraman, A., Zeithaml, V. A., Berry, L. L. SERVQUAL: A multiple item scale for measuring consumer perception of service quality. Journal of Retailing, 64 (1), pp. 12-37. 1988. https://www.scirp.org/reference/ReferencesPapers.aspx?ReferenceID=1989178

[45] Mahapatra, S.S. \& Khan, M.S., "A Methodology for Evaluation of Service Quality Using Neural Networks," in Proceedings of the International Conference on Global Manufacturing and Innovation,' July 27 29, 2006. http://citeseerx.ist.psu.edu/viewdoc/download?doi=10.1.1.595.7915\&rep=rep1\&type=pdf

[46] Whitler, Kimberly A. , and Morgan, Neil A. "Why CMOs Never Last," Harvard Business Review (July/August), 46-54. 2017. https://hbr.org/2017/07/the-trouble-with-cmos

[47] Huffman, C., \& Kahn, B. E. Variety for sale: Mass customization or mass confusion? Journal of Retailing, 74 (4), 491-513. 1998. Doi: 10.1016/S0022-4359(99)80105-5.

[48] Nitin Seth, S.G. Deshmukh, Prem Vrat, "Service quality models: a review", International Journal of Quality \& Reliability Management, Vol. 22 Issue: 9, pp. 913-949, 2005. https://doi.org/10.1108/02656710510625211

[49] Surendra Jagwan, SERVQUAL model Service Quality Gaps, 2017. https://professionalshiksha.blogspot.com/2017/10/service-quality-gap-model.html

[50] Ladhari, R. Alternative measures of service quality- A review. Managing Service Quality, 18 (1), pp. 6586. 2008. http://www.academia.edu/6113475/Alternative_measures_of_service_quality_a_review

[51] Lai, T. L. Service quality and perceived values impact on satisfaction, intention and usage of Short Message

Service (SMS). International Systems $\quad$ Frontiers, $6 \quad$ (4), pp. $\quad 353-368.2004$. https://link.springer.com/article/10.1023/B:ISFI.0000046377.32617.3d

[52] Cronin, J., Taylor, S. SERVPERF versus SERVQUAL: Reconciling performance based and perceptions minus expectations and measurement of service quality. Journal of Marketing, 58 (1), pp. 125-131. 1994. http://www.sciepub.com/reference/159658

[53] Cronin, J., Taylor, S. Measuring service quality: A re-examination and extension. Journal of Marketing, 56 (3), pp. 55-68. 1992. http://www.sciepub.com/reference/199894

[54] Brogowicz, A. A., Delene, L. M., \& Lyth, D. M. A synthesized service quality model with managerial

Implication of results. International Journal of Service Industry Management, 1(1), 27-44. 1990. http://dx.doi.org/10.1108/ 09564239010001640

[55] Gilbert, D., Wong, R. K. C. Passenger expectations and airline services: A Hong Kong based study. 
Tourism Management, $\quad 24, \quad$ pp. 2003. 2003.https://www.academia.edu/8200425/Passenger_expectations_and_airline_services_a_Hong_Kong_base d_study

[56] Brady, M. K., Cronin, J. J. Some new thoughts on conceptualizing perceived service quality: A hierarchical approach. Journal of Marketing, $65 \quad$ (3), pp. 34-49. 2001. https://www.scirp.org/(S(vtj3fa45qm1ean45vvffcz55))/reference/ReferencesPapers.aspx?ReferenceID=12987 02

[57] Jochen Wirtz, Services Marketing, People, Technology, Strategy, 2016. https://doi.org/10.1142/y0001, https://www.worldscientific.com/worldscibooks/10.1142/y0001

[58] M. Rafiq and P. K. Ahmed, "Using the 7Ps as a Generic Marketing Mix: an Exploratory Survey of UK and European Marketing Academics," Marketing Intelligence \& Planning, Vol. 13, No. 9, pp. 4-15. 1995, doi:10.1108/02634509510097793

[59] MYMG TEAM, The Importance of Market Research Explained, or Why You should Research Markets, Business and Finance, 2011. https://mymanagementguide.com/the-importance-of-market-research-explainedor-why-you-should-research-markets/

[60] Mats Urde, "Core value based corporate brand building", European Journal of Marketing, Vol. 37 Issue: 7/8, pp. 1017-1040, 2003. https://doi.org/10.1108/03090560310477645

[61] Ballantyne, D., \& Varey, R. J. Introducing a Dialogic orientation to the service-dominant logic of marketing in R. F. Lusch \& S. L. Vargo (Eds.), The service-dominant logic of marketing: Dialog, debate, and directions. $\quad$ Armonk: $\quad$ M.E. $\quad$ Sharpe. 2006. https://books.google.co.in/books?hl=en\&lr=\&id=JczfBQAAQBAJ\&oi=fnd\&pg=PA224\&ots=Qn-vvEp3-

$3 \&$ sig=AmxWZNjJRYpUm9rdPNBGYiESItA\&redir_esc=y\#v=onepage $\& \mathrm{q} \& \mathrm{f}=$ false

[62] Kevin E. Voss and Mayoor Mohan. Corporate brand effects in brand alliances. Journal of Business $\begin{array}{lllllll}\text { Research } & \text { Vol. } & 69, & \text { Issue. } & \text { 10, }\end{array}$ https://www.sciencedirect.com/science/article/abs/pii/S0148296316300224?via\%3Dihub

[63] Andreas Levering, Veronica Liljander, "Does relationship marketing improve customer relationship satisfaction and loyalty?", International Journal of Bank Marketing, Vol. 24 Issue: 4, pp. 232-251, 2006. https://doi.org/10.1108/02652320610671333

[64] Vinita Kaura, Ch. S. Durga Prasad, Sourabh Sharma, "Service quality, service, convenience, price and fairness, customer loyalty, and the mediating role of customer satisfaction", International Journal of Bank Marketing, Vol. 33 Issue: 4, pp.404-422, 2015. https://doi.org/10.1108/IJBM-04-2014-0048

[65] Ghauri, P. \& T. Fang, 'Negotiating with the Chinese: a Social-cultural analysis', Journal of World $\begin{array}{llll}\text { Business, } & 36 & (3), & 303-25 .\end{array}$ https://www.academia.edu/432862/Ghauri_and_Fang_2001_._Negotiating_with_the_Chinese_A_sociocultural_analysis

[66] John K. Lynam \& Robert W.Herdt, Sense and sustainability, Sustainability as an objective, Agricultural Economics, Volume 3, Issue 4, Pages 381-398, https://www.sciencedirect.com/science/article/pii/0169515089900108

[67] Ken Peffers, Tuure Tuunanen, Marcus A. Rothenberger \& Samir Chatterjee, A Design Science Research Methodology for Information Systems Research, Journal of Management Information Systems, 24:3, 45-77, 2007. DOI: 10.2753/MIS0742-1222240302

[68] Suhail Ahmad Bhat, Mushtaq Ahmad Darzi, "Customer relationship management: An approach to competitive advantage in the banking sector by exploring the Media role of loyalty", International Journal of Marketing, Vol. 34 Issue: 3, pp.388-410, 2016. https://doi.org/10.1108/IJBM-11-2014-0160

[69] V. Kumar, Nita Umashankar, Kihyun Hannah Kim, Yashoda Bhagwat. Assessing the Influence of Economic and Customer Experience Factors on Service Purchase Behaviors. Marketing Science, 2014; 
140703074314002 DOI: $10.1287 / \mathrm{mksc} .2014 .0862$

[70] Christian Grönroos, Annika Ravald, "Service as business logic: implications for value creation and marketing", Journal of Service Management, Vol. 22 Issue: 1, pp.5-22, 2011. https://doi.org/10.1108/09564231111106893

[71] Stephen J. Grove, Raymond P. Fisk, Joby John, "The future of services marketing: forecasts from ten services experts", Journal of Services Marketing, Vol. 17 Issue: 2, pp.107-121, 2003. https://doi.org/10.1108/08876040310467899

[72] Rajendra S. Sisodia, "Expert Systems for Services Marketing - Prospects and Payoffs", Journal of Services Marketing, Vol. 5 Issue: 3, pp.37-54, 1991. https://doi.org/10.1108/08876049110035611

[73] Sheena Leek, Peter Naudé, Peter W. Turnbull, Interactions, relationships and networks in a changing world, Industrial Marketing Management, Volume 32, Issue 2, Pages 87-90, 2003, https://www.sciencedirect.com/science/article/abs/pii/S0019850102002225

[74] Riza Casidy and Walter Wymer. A risk worth taking: Perceived risk as moderator of satisfaction, loyalty, and willingness-to-pay premium, price. Journal of Retailing and Consumer Services 32, 189-197. 2016. https://www.sciencedirect.com/science/article/pii/S0969698916301539?via\%3Dihub

[75] Ivan K.W. Lai, Michael Hitchcock, Ting Yang, Tun-Wei Lu, "Literature review of service quality in hospitality and tourism, Future directions and trends", International Journal of Contemporary Hospitality Management, Vol. 30 Issue: 1, pp. 114-159, 2018. https://doi.org/10.1108/IJCHM-08-2016-0408

[76] Usman Ahmad Qadri, Measuring Service Quality Expectation and Perception Using SERVQUAL, Business and Economics Journal, 2015. https://www.omicsonline.org/open-access/measuring-service-qualityexpectation-and-perception-using-servqual-a-gap-analysis-2151-6219-1000162.php?aid=58151

[77] Christian M. Ringle, Marko Sarstedt, (2016) "Gain more insight from your PLS-SEM results: The importance-performance map analysis", Industrial Management \& Data Systems, Vol. 116 Issue: 9, pp. 18651886, https://doi.org/10.1108/IMDS-10-2015-0449

[78] Luvai F. Motiwalla, Vidyaranya B. Gargeya, "Expert Systems in Service Operations", Industrial Management \& Data Systems, Vol. 92 Issue: 8, pp. 14-19, 1992. https://doi.org/10.1108/02635579210019820

[79] K. Metaxiotis, John Psarras, "Expert systems in business: applications and future directions for the operations researcher", Industrial Management \& Data Systems, Vol. 103 Issue: 5, pp. 361-368, 2003. https://doi.org/10.1108/02635570310477

(80) Kotler, Philip; Armstrong, Gary, Principles of Marketing, ISBN: 9789332558472, 2015. https://biblio.co.uk/principles-of-marketing-by-kotler-philip-armstrong/work/53762

[81] Hitesh Bhasin, Service triangle or The service marketing triangle, 2017, https://www.marketing91.com/service-triangle/

[82] Philip Kotler and Gary Armstrong "Marketing an introduction" 5th edition pp, 459, 2015. https://biblio.co.uk/principles-of-marketing-by-kotler-philip-armstrong/work/53762

[83] Stephen L. Vargo, Robert F. Lusch, The Four Service Marketing Myths: Remnants of a Goods-Based, $\begin{array}{llllll}\text { Manufacturing } & \text { Model, } & \text { Vol. } & 6, & \text { Issue } & 4,\end{array}$ https://journals.sagepub.com/doi/abs/10.1177/1094670503262946

[84] Vinita Kaura, Ch. S. Durga Prasad, Sourabh Sharma, "Service quality, service, convenience, price and fairness, customer loyalty, and the mediating role of customer satisfaction", International Journal of Bank Marketing, Vol. 33 Issue: 4, pp. 404-422, 2015. https://doi.org/10.1108/IJBM-04-2014-0048

[85] Zeithaml, Valerie A., Berry, Leonard L. \& Parasuraman, A. "The behavioral consequences of service quality," Journal of Marketing, Vol. $60 \quad$ (2), p.31-46, 1996. https://www.researchgate.net/publication/248768479_The_Behavioral_Consequences_of_Service_Quality. 